$$
\begin{gathered}
\text { Artikel-05- } \\
\text { Tsania_Khairani_0305201018.p } \\
\text { df } \\
\text { by }
\end{gathered}
$$

Submission date: 24-Dec-2021 05:43PM (UTC+0700)

Submission ID: 1735476488

File name: Artikel-05-Tsania_Khairani_0305201018.pdf (308K)

Word count: 3418

Character count: 22316 


\title{
PENGENALAN ALGORITMA PADA PEMBELAJARAN PEMROGRAMAN KOMPUTER
}

\author{
Tsania Khairani Aritonang (0305201018) \\ 13 Prodi Pendidikan Matematika-1 \\ Fakultas Ilmu Tarbiyah dan Keguruan \\ UIN Sumatera Utara \\ Email : tsaniaaritonang@gmail.com
}

\begin{abstract}
ABSTRAK
Algoritma memiliki pengertian sebagai sekumpulan tindakan untuk menyelesaikan suatu persoalan. Tindakan penyelesaian yang dilakukan haruslah berurutan, logis dan sistematis. Dengan begitu algoritma dapat dijadikan landasan dalam pembuatan program komputer. Sedangkan program komputer merupakan sekumpulan perintah yang diinstruksikan untuk dilakukan oleh komputer saat memecahkan sebuah persoalan. Algoritma sangat berperan penting pada pemrograman komputer karena sentral dari ilmu komputer adalah algoritma. Pembahasan dari cabang-cabang bidang komputer banyak yang menunjuk pada definisi algoritma. Tujuan dibuatnya karya ilmiah ini adalah untuk membantu mahasiswa supaya dapat mengenali terlebih dahulu definisi dari algoritma sehingga dapat mempermudah pemahaman mahasiswa pada pembelajaran pemrograman komputer serta meningkatkan motivasi mahasiswa dalam pembelajaran. Penulis memakai metode studi literatur dalam menulis karya ilmiah ini.
\end{abstract}

Kata kunci : Algoritma, Pemrograman.

\section{PENDAHULUAN}

Kemajuan ilmu teknologi dan informasi sangat berdampak besar dalam kehidupan. Kemajuan tersebut berdampak baik dan dapat dirasakan oleh setiap manusia contohnya seperti kemudahan dalam mengakses ilmu pengetahuan dan kemudahan dalam berkomunikasi antara satu sama lain.

Perkembangan teknologi dan informasi membuat perubahan besar pada kehidupan, terutama dalam bidang pendidikan. Perkembangan tersebut melahirkan persaingan yang semakin ketat sehingga menuntut para peserta didik 
harus dapat mengimbangi perkembangan teknologi agar dapat terus bersaing pada zaman globalisasi.

Salah satu mata kuliah wajib dalam program studi pendidikan matematika adalah algoritma pemrograman. Pembahasannya mengenai konsep dasar algoritma pemrograman, penyajian algoritma serta bahasa pemrograman.

Kata algoritma sangat melekat dengan pemrograman komputer karena algoritma sendiri merupakan sebuah penyelesaian permasalahan dari sebuah perintah yang diinstruksikan kepada komputer untuk menyelesaikan sebuah masalah. Dapat dikatakan bahwa algoritma merupakan alur yang harus digunakan dalam menyelesaikan suatu pekerjaan atau tugas.

Karena algoritma mengandung pemecahan suatu masalah maka ia juga dapat disebut solusi. Solusi tersebut berasal dari sebuah masalah yang harus dipecahkan oleh komputer.

Algoritma sangat berhubungan dengan pemrograman komputer. Namun bukan berarti algoritma harus selalu identik dengan pemrograman komputer. Dengan kata lain tidak semua langkah harus kita ikuti namun langkah-langkah tersebut dapat dimodifikasi atau bahkan dibuat ulang dengan tujuan menyelesaikan persoalan.

Algoritma sering dikaitkan dengan ilmu komputer, tetapi kenyataannya algoritma banyak digambarkan dalam kehidupan sehari-hari contohnya yaitu petunjuk memasak dan membuat minuman yang diterangkan pada sebuah buku resep ataupun cara menggunakan sebuah mesin yang dinyatakan dalam sebuah buku panduan.

\section{Metode Penelitian}

Algoritma memiliki asal kata "algorism" mengacu pada seorang penulis terkenal yang berasal dari arab yakni Abu Ja'far Muhammad Ibnu Musa alKhuwarizmi yang hidup pada masa tahun 770 M. Ia merupakan salah satu ilmuwan yang terkenal pada zamannya. Semua idenya dijelaskan secara logis dan diterapkan sebagai metode algoritma dalam proses kerja matematika komputer.

Dalam penelitian ini akan dijabarkan mengenai pengertian algoritma, ciri-ciri dan sifat algoritma, struktur algoritma, notasi algoritma. Dalam karya ilmiah ini 
juga akan menjabarkan tentang pengertian pemrograman serta bagaimana hubungan antara algoritma dan pemrograman.

Dalam menyusun karya ilmiah ini penulis memakai sebuah metode yaitu metode studi literatur. Penulis mengunjungi halaman pencarian dengan keyword"Algoritma Pemrograman", di sana terdapat banyak buku-buku dan jurnal yang berbahasa asing dan bahasa Indonesia yang dapat digunakan sebagai bahan referensi.

Ada beberapa ketentuan dalam menyelesaikan karya ilmiah ini yaitu:

1. Ketentuan pertama yaitu karya ilmiah harus memiliki referensi minimal 10 jurnal. Jurnal tersebut bertemakan tentang algoritma pemrograman. Kemudian jurnal yang dipakai harus memiliki tahun terbit dimulai dari tahun 2015.

2. Ketentuan kedua yaitu karya ilmiah harus memiliki referensi minimal dari 2 buku. Buku yang penulis gunakan adalah buku pertama yang berjudul "Algoritma Pemrograman" yang ditulis oleh Edy Budiman. Buku kedua berjudul "Bahasa Pemrograman" yang ditulis oleh Suprapto. Buku ketiga berjudul "Matematika Diskrit" yang ditulis oleh Rinaldi Munir.

3. Ketentuan ketiga yaitu karya ilmiah harus memiliki minimal kata yang berjumlah 3000 kata dan minimal halaman yang berjumlah 10 halaman.

\section{PEMBAHASAN}

\section{Pengertian Algoritma}

Jika ditelusuri lebih dalam kata algoritma mempunyai asal usul yang Kata algorism hanya diketahui sebagai aktivitas berhitung pada kaum Arab. Dan orang yang memakai angka Arab tersebut dalam berhitung akan dinamakan algorist.

Setelah ditelusuri kembali oleh sejarawan matematika akhirnya ditemukanlah asal dari kata algorism. Kata algorism diambil dari nama seorang penulis terkenal dari bangsa Arab yakni Abu Ja'far Muhammad Ibnu Musa alKhuwarizmi. Ia menciptakan sebuah buku yang diberi judul kitab aljabar walmuqabala, dengan arti " Buku Pemugaran dan Pengurangan" ( The book of restoration and reduction). Kemudian ditemukanlah akar kata "Aljabar"(algebra) 
pada judul buku tersebut. Karena perhitungan dengan angka Arab semakin populer pada masa itu maka lambat laun istilah tersebut diserap oleh bahasa Indonesia dan menjadikannya algoritma.

Pengertian algoritma berdasarkan Microsoft Press Computer and Internet Dictionary (1998) merupakan deretan dari sekumpulan rangkaian tindakan tertentu yang pastinya logis dalam menyelesaikan persoalan. Logis di sini memiliki arti bahwa tindakan yang dilakukan harus sesuai dengan urutan dan tersusun secara runtut serta langkah tersebut harus diketahui dengan pasti agar algoritma yang dipakai dapat berjalan semestinya.

Sjukani (2005) berpandangan bahwa algoritma merupakan jalan pikiran yang digunakan saat penyelesaian sebuah operasi yang dijabarkan dalam bentuk tertulis. Alur pikir disini mengisyaratkan bahwa jalan pikiran seseorang dapat berbeda dengan yang lainnya. Sementara itu makna tertulis berbentuk kalimat, tabel, atupun gambar tertentu yang dapat ditulis.

Dalam pandangan Gunadarma (1988) definisi algoritma merupakan gabungan dari sekumpulan perintah yang menjabarkan langkah-langkah yang jelas saat prosedur pelaksanaan memecahkan sebuah permasalahan, dengan tuntutan himpunan bersifat mekanik.

Dapat disimpulkan definisi algoritma adalah ilmu yang membahas caracara penyelesaian sebuah persoalan dengan deretan langkah tertentu kemudian tersusun dengan sistematis dan memakai bahasa logis serta memiliki sebuah tujuan .

Algoritma merupakan skema kerja komputer yang dilengkapi dengan perangkat otak (brainware), perangkat lunak (software) dan perangkat keras (hardware). Sistem komputer tidak akan bertindak dengan baik apabila tanpa ketiga perangkat tersebut.

Algoritma yang disebutkan dalam referensi lain adalah suatu proses serangkaian perintah-perintah yang berkonsolidasi, atau cara spesial dalam memecahkan persoalan yang praktis (webster kamus). Banyak sekali gambaran maupun implementasi algoritma yangtidak kita sadari dapat kita lihatdan temukan pada kehidupan kita sehari-hari. Berikut merupakan contoh sederhana dari algoritma : 


\section{Contoh 1}

Tips memasak kue yang dijabarkan pada sebuah buku resep. Misalnya buku resep membuat kue lapis yaitu contoh dari sebuah algoritma dengan langkah-langkah sebagai berikut :

1. Panaskan santan beserta daun pandan selama 15 menit. Setelah itu tunggu hingga dingin kembali.

2. Masukkan tepung tapioka dan beras, vanili, garam, gula dan air kedalam wadah kemudian campurkan dan aduk rata.

3. Setelah itu tuangkan santan yang telah dingin ke atas wadah dan aduk hingga adonan tidak menggumpal.

4. Hidupkan kompor dan panaskan panci kukusan. Lalu tutup menggunakan kain bersih.

5. Pisahkan adonan menjadi 2 bagian. Sebagian akan diberikan pasta pandan dan bagian lainnya akan tetap berwarna putih.

6. masukkan 3 sendok makan adonan berwarna putih ke dalam cetakan. Kemudian kukus hingga 5 menit. masukkan 3 sendok makan lagi adonan berwarna pandan diatas adonan putih tunggu hingga 5 menit. Begitu seterusnya.

7. Jika adonan sudah habis, kukus kembali adonan hingga 20 menit sampai matang sempurna.

8. Setelah adonan masak dan dingin kue dapatdipotong sesuai selera.

9. Kue dapat disajikan.

Contoh 2

Cara menentukan luas lingkaran dinyatakan dalam sebuah rumus.

Misalnya penggunaan algoritma digunakan untuk mencari satuan luas dari lingkaran, yaitu dengan cara:

1. Temukan nilai jari-jari (r) dari sebuah lingkaran.

2. Kemudian carilah nilai phi $(\pi)$.

3. Cara menentukan luasnya dengan mengalikan nilai dari jari-jari (r) yang sudah didapatkan sebanyak 2 kali kemudian dengan nilai phi $(\pi)$ dikalikan kembali.

4. Sehingga kita akan mendapatkan nilai luas lingkaran.

5 . pencarian selesai. 
Implementasilain dari algoritma selain resep kue dalam kehidupan seharihari misalnya pengisian voucher, pola pakaian, panduan merakit, panduan praktikum, jadwal harian, dan papan not balok ditunjukkan pada tabel berikut ini.

\begin{tabular}{|c|c|c|}
\hline Proses & Algoritma & Contoh Langkah dalam Algoritma \\
\hline $\begin{array}{l}\text { 1. Memasak kue } \\
3 \\
\end{array}$ & $\begin{array}{l}\text { Buku Resep } \\
\text { kue }\end{array}$ & $\begin{array}{l}\text { Masukkan kue kedalam oven tunggu } \\
\text { hingga } 30 \text { menit. }\end{array}$ \\
\hline 2. Mengisi voucher & Kertas & Ketik nomor 123 kemudian masukkan \\
\hline $\begin{array}{l}\text { kartu telepon } \\
\text { genggam }(H P)\end{array}$ & $\begin{array}{l}\text { Panduan } \\
\text { pengisian }\end{array}$ & nomor yang ada pada voucher \\
\hline 3. Menjahit pakaian & Buku desain & $\begin{array}{l}\text { Gunakan benang berwarna merah saat } \\
\text { menjahit lengan atas baju }\end{array}$ \\
\hline $\begin{array}{l}\text { 4. Merakit permainan } \\
\text { lego }\end{array}$ & $\begin{array}{l}\text { Buku } \\
\text { panduan } \\
\text { merakit }\end{array}$ & Keluarkan semua item dari kotak. \\
\hline 5. Praktikum kimia & $\begin{array}{l}\text { Panduan } \\
\text { praktikum }\end{array}$ & $\begin{array}{l}\text { Masukkan } 5 \mathrm{ml} \mathrm{NaOH} \text { dengan } 10 \mathrm{ml} \\
\mathrm{H}_{2} \mathrm{SO} 4\end{array}$ \\
\hline 6. Keseharian & $\begin{array}{l}\text { Skema } \\
3 \\
\text { jadwal harian }\end{array}$ & $\begin{array}{l}\text { Pukul } 20.00 \text { : belajar, pukul } 22.00 \text { : } \\
\text { tidur }\end{array}$ \\
\hline 7. Bermain musik & $\begin{array}{l}\text { Buku not } \\
\text { nada }\end{array}$ & Not balok setiap lagu \\
\hline
\end{tabular}

abel 1. Contoh-contoh algoritma dalam Kehidupan Sehari-hari

\section{Ciri-ciri dan Sifat Algoritma}

Walaupun langkah penyelesaian masalahnya sudah berurutan dan juga logis namun hal tersebut belum dapat dikatakan sebagai algoritma. Karena menurut seorang ahli Donald E.Knuth, ia berpendapat bahwa algoritma memiliki beberapa ciri khusu yaitu :

1. Finiteness (keterbatasan), maksudnya adalah sebuah algoritma diharuskan menghasilkan suatu jawaban atau solusi apabila sejumlah langkah proses penyelesaian telah diselesaikan. 
2. Definiteness (kepastian), semua intruksi yang dilakukan haruslah benar dan tepat namun intruksi tidak dapat ganda atau lebih dari satu.

3. Input (masukan), harus memiliki masukan (input).

4. Output (keluaran), harus memiliki keluaran (output).

5. Effectiveness (efektivitas), intruksi yang diperintahkan harus sederhana namun tetap efektif supaya mudah dipahami oleh pemroses sehingga waktu yang dipakai dapat lebih singkat.

Berikut sifat-sifat algoritma yaitu :

1. Bahasa yang digunakan dalam pemrograman tidak boleh memakai lambang dari bahasa pemograman yang lain.

2. Bahasa yang digunakan kan tidak bergantung pada ada bahasa pemrograman lainnya.

3. Seluruh notasi dapat dipakai oleh seluruh bahasa.

4. Algoritma dapat digunakan dalam mempresentasikan atau menjelaskan sebuah deretan peristiwa yang valid sehingga penerapannya dapat digunakan dalam semua aspek kehidupan.

\section{Struktur Algoritma}

Algoritma memiliki struktur dasar yaitu sekumpulan perintah-perintah. Tiga unsur dasar dari algoritma yaitu runtunan, pemilihan dan pengulangan. Langkah-langkah tersebut akan membuat sebuah kontruksi dalam algoritma. Dibawah ini penjelasan struktur tersebut:

\section{Runtunan (sequence)}

Runtunan mencangkup intruksi satu ataupun lebih. Penulis harus mengerjakan setiap intruksi sesuai dengan urutannya, satu persatu dan tidak boleh melangkap dari urutan sebelumnya dan apabila urutannya diacak atau diubah maka hasilnya juga pasti berubah karena sebuah intruksi sanagt menentukan keadaan dari akhir algoritma.

Semua struktur intruksi harus dilakukan berentetan dan dilaksanakan satu persatu. Mulai dari perintah yang pertama hinga terakhir, tidak boleh diloncat apalagi diulangi. Prosesnya dilakukan sebagai berikut :

- Semua perintah dilakukan bertahap. 
- Semua perintah hanya dilakukan sekali sehingga tidak ada perintah yang dua kali.

- Rentetan perintah yang dilakukan oleh pemroses akan sama dengan perintah yang tertulis didalam teks algoritma.

- Perintah terakhir merupakan tujuan algoritma.

Dampak dari runtunan

- Rangkaian urutan perintah adalah hal yang paling penting dalam algoritma.

Deretan perintah tersebut merupakan runtunan dari logika pengelolaan permasalahan.

- Urutan perintah yang berlainan akan sangat berpengaruh pada saat penyelesaian persoalan, dan pasti akan memiliki keluaran yang berbeda pula, tegantung masalah yang dihadapi.

Contohnya dapat kita lihat dalam operasi aritmetika berikut ini, $5+(5-1) 7=33$, tetapi apabila urutannya diganti maka akan memiliki hasil akhir yang berbeda menjadi $5+5-(1 * 7)=3$

2.Pemilihan (selection)

Biasanya sebuah permasalahan dapat dikerjakan dengan beberapa cara alternatif dalam melaksanakan sebuah aksi. Aksi tersebut dapat diselesaikan apabila kondisinya terpenuhi. Contohnya jika sebuah masalah mempunyai sejumlah kasus, dan untuk menyelesaikannya harus dilaksanakan dengan cara analisis pada setiap kasus dan persoalan yang ada kemudian kita harus menentukan aksi apa yang akan kita lakukan pada sebuah masalah. Sejumlah perintah dapat dilakukan apabila keadaan sebelumnya bernilai positif namun jika kondisi tersebut bernilai salah maka perintah tidak akan bisa dilakukan.

Struktur pemilihan memiliki sebuah contoh, misalnya dalam menetapkan nilai seorang murid apakah ia memperoleh nilai A, B, C ataupun D. Saat mengurutkan algoritma dalam menyusun nilai para murid kita wajib mencadangkan beberapa cara alternatif lainnya sesuai dengan ketentuan yang benar, contohnya sebagai berikut :

- Opsi 1 : apabila bernilai $>90$ maka nilainya A.

- Opsi 2 : apabila bernilai antara 80 sampai dengan 90 maka nilainya B.

- Opsi 3 : apabila bernilai antara 70 sampai 80 maka nilainya C. 
- Opsi 4 : apabila bernilai < 70 maka nilainya D.

Tiap-tiap murid pastinya memiliki nilai yang beragam dengan kisaran 1 hingga 100, apabila kita menggunakan algoritma dalam menyusun nilai dari para murid, maka nilai-nilai tersebut akan diproses sehingga menjadikan nilai para murid menjadi bergolongan yaitu golongan A, B, C dan D sesuai dengan opsi diatas.

Contohnya apabila seorang murid mendapatkan nilai 98 maka ia akan masuk kedalam golongan A karena nilainya berada diatas 90 namun apabila ia mendapatkan nilai 75 maka ia akan masuk ke golongan $\mathrm{C}$ karena nilainya berada antara 70 dan 80.

Proses struktur prmilihan yang digunakan seperti ilustrasi diatas akan memberikan beberapa keputusan dan opsi yang sesuai dengan kondisi.

3. Pengulangan (repetition)

Didalam algoritma struktur pengulangan adalah operasi algoritma yang berulang saat melakukan sejumlah perintah sesuai dengan jumlah yang telah ditentukan dan kondisi tertentu.

Dalam algoritma bisa saja beberapa kasus tertentu memuat struktur pengulangan, dan bisa juga kasus yang akan diselesaikan tidak bersesuaian. Pengulangan tersebuat dibuat agar mempermudah dalam menyajikan algoritma supaya sistemnya berjalan lebih cepat dan penulisan algoritma menjadi lebih sederhana.

Misalnya : saat mengetik kalimat "Aku suka matematika" dengan jumlah 2500 baris. Untuk mengetik kalimat sebanyak itu maka ada 2 cara alternatif yang bisa digunakan dan tentunya keduanya benar.

Opsi yang pertama yaitu dengan mengetikkan perintah ketik kalimat "aku suka matematika" dengan jumlah 2500 kali. Opsi yang kedua yaitu dengan memakai struktur pengulangan. Apabila opsi yang digunakan pada cara pertama tidak efektif karena diketik secara manual dengan jumlah 2500 baris kalimat "Aku suka matematika", jika kita mengetiknya secara manual kita pastinya akan kepayahan. Maka adanya struktur pengulangan dapat memberikan alternatif dengan praktis hanya dengan beberapa intruksi saja bisa selesai.

\section{Notasi Algoritma}


Notasi merupakan aturan penulisan dalam algoritma. Notasi algoritma tidak bergantung pada pengkhususan sebuah bahasa pemrograman tertentu maupun sistem komputer yang menjalankannya. Dikarenakan notasi algoritma bukan hanya sebatas notasi bahasa pemrograman tetapi melainkan bahasa global yang dapat diterima pada semua bahasa pemrograman yang ada.

Notasi algoritma diuraikan ke dalam tiga bentuk yaitu kalimat deskriptif algoritma, pseudo code dan flow chart.

\section{Deskriptif Algoritma}

Kalimat deskriptif merupakan bentuk notasi yang sangat efektif dan sederhana karena hanya memakai bahasa dan kalimat yang dipakai dalam kehidupan sehari-hari. Notasi ini jarang digunakan saat persoalan menjadi lebih kompleks dan sulit karena sering terjadinya ambigu dalam langkah penyelesaian sehingga sulit untuk dipahami.

Notasi ini sangat cocok untuk diterapkan pada algoritma yang bersifat pendek dan mudah. Namun untuk persoalan yang kompleks dan rumit mengatasinya rasanya kurang cocok dan kurang pas. Penulisan pada notasi dengan bentuk bahasa deskriptif adalah cara yang paling mudah dibuat namun cara ini merupakan cara yang paling sukar saat diterjemahkan ke dalam bahasa pemrograman.

\section{Pseudocode}

Pseudo-code berasal dari kata "Pseudo" dan "code" ( pseudo artinya semu atau tidak sebenarnya). Pseudocode merupakan bentuk notasi yang menyerupai bahasa pemrograman karena memiliki struktur seperti Pascal. Para ilmuwan sangat menyukai notasi ini karena lebih praktis.

Dalam pseudocode, garis bawah harus digunakan untuk kata algoritma (yang diikuti oleh judul dari algoritma), kata deklarasi, kata deskripsi, tipe data, read, write, if, else, end if, for, end for, while, end while, do while dan end do while.

Keuntungan dalam menggunakan notasi ini adalah kemudahan dalam menerjemahkannya ke notasi bahasa pemrograman karena terdapat kesinambungan antara setiap pseudocode dengan notasi bahasa pemrograman.

3. Flow Chart 
Flowchart merupakan bentuk notasi yang dituliskan dalam bentuk grafis. Flowchart menggunakan gambar atau simbol tertentu untuk menggambarkan urutan langkah penyelesaian dari awal hingga akhir pada suatu program. Dengan demikian setiap simbol menggambarkan proses tertentu.

Tidak ada patokan mutlak untuk membuat sebuah diagram alir program karena merupakan gambaran dari hasil analisis masalah komputer sehingga diagram alir hasilnya dapat berbeda-beda antara satu programmer dengan programmer lainnya.

Kelemahan cara ini adalah dalam penyusunan algoritma sangat dipengaruhi oleh tata bahasa pembuatannya sehingga terkadang orang lain yang akan sulit dalam menerjemahkannya.

\begin{tabular}{|c|c|c|c|}
\hline No. & Simbol Flowchart & Nama & Arti Simbol Flowchart \\
\hline 1 & & Terminator & $\begin{array}{l}\text { Awal atau akhir konsep } \\
\text { (prosedur) }\end{array}$ \\
\hline 2 & & Process & Proses operasional \\
\hline 3 & & Document & $\begin{array}{l}\text { Dokumen atau laporan berupa } \\
\text { print out }\end{array}$ \\
\hline 4 & & Decision & $\begin{array}{l}\text { Keputusan atau sub-point. } \\
\text { Garis yang terhubung dengan } \\
\text { bentuk decision merujuk pada } \\
\text { situasi-situasi yang berbeda } \\
\text { sesuai dengan keputusan yang } \\
\text { digambarkan }\end{array}$ \\
\hline 5 & & Data & $\begin{array}{l}\text { Input dan Output (Contohnya, } \\
\text { Input: feedback dari } \\
\text { pelanggan. Output: desain } \\
\text { produk baru) }\end{array}$ \\
\hline 6 & & $\begin{array}{l}\text { On-Page Reference/ } \\
\text { Connector }\end{array}$ & $\begin{array}{l}\text { Penghubung alur dalam } \\
\text { halaman yang sama }\end{array}$ \\
\hline 7 & & $\begin{array}{l}\text { Off-Page Reference/ } \\
\text { Off-Page Connector }\end{array}$ & $\begin{array}{l}\text { Penghubung alur dalam } \\
\text { halaman yang berbeda }\end{array}$ \\
\hline 8 & & Flow & $\begin{array}{l}\text { Arah alur dalam konsep } \\
\text { (prosedur) }\end{array}$ \\
\hline
\end{tabular}

Gambar 1. Simbol-Simbol Flow Chart

2

Contoh Flowchart untuk Menentukan Bilangan yang Genap dan Ganjil 
Algoritma dari menentukan sebuah bilangan tersebut genap atau ganjil, yaitu :

- Pertama yaitu masukkan suatu bilangan, bilangan tersebut haruslah bilangan bulat.

- Lalu bagi bilangan yang telah dimasukkan tersebut dengan angka 2 .

- Apabila hasil dari sisa pembagian tersebut 0 , maka dapat disimpulkan bahwa bilangan tersebut adalah genap.

- Sebaliknya, apabila hasil dari sisa pembagian tersebut bukan 0, maka dapat disimpulkan bahwa bilangan tersebut adalah ganjil.

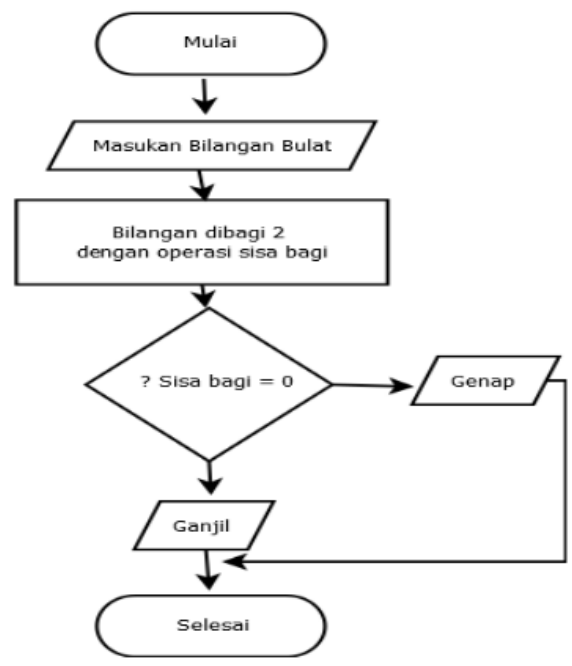

Gambar 2. Contoh Flow Chart Menentukan Bilangan Genap dan Ganjil

\section{Pengertian Pemrograman}

Asal dari kata pemrograman yaitu program yang artinya kumpulan instruksi yang dituliskan untuk melakukan suatu hal fungsi spesifik pada komputer, sedangkan pemrograman adalah segala sesuatu yang berkaitan dengan pembuatan program menggunakan komputer. Komputer memerlukan keberadaan program agar bisa menjalankan fungsinya sebagai komputer.

Program adalah perwujudan atau implementasi algoritma yang ditulis dalam bahasa pemrograman tertentu sehingga dapat dilaksanakan oleh komputer. Program dibuat berdasarkan sebuah bahasa pemrograman tertentu, dan pekerjaan merancang program disebut pemrograman (programming). Pelaku yang merancang program disebut pemrogram (programmer). Sedangkan setiap 
langkah pada program disebut perintah atau instruksi. Sehingga, program terdiri dari sekumpulan instruksi. Jika sebuah instruksi dikerjakan akan bersesuaian antara operasi dan instruksi pada aktivitas di komputer.

Pemrograman merupakan sebuah aktivitas atau prosedur yang dipakai saat mengimplementasikan suatu algoritma dengan menggunakan bahasa-bahasa yang sudah ada dalam sistem pemrograman (Budi, 2000:21). Pemrograman mempunyai tujuan yaitu agar dalam membuat sebuah program, dapat dilakukan dengan perhitungan yang bisa dicerna oleh komputer sesuai dengan keinginan user. Maka dari itu saat melaksanakan sebuah pemrograman, sangat dibutuhkan kepandaian dalam bidang algoritma seperti algoritma, bahasa pemrograman, pengetahuan matematika, serta logika.

Definisi lain dari pemrograman yaitu "komunikasi" yang dimaksudkan khusus diantara programmer lainnya dan komputer yang memakai bahasa pemrograman. Bahasa pemrograman merupakan bahasa yang mudah dipahami atau dapat diterjemahkan oleh mesin dan memungkinkan pengguna user untuk menentukan data yang akan diproses oleh komputer atau sebagaimana data tersebut akan dikemakan dan langkah harus diambil dalam setiap macam kondisi.

Purnamasari (2005:2) mengatakan yaitu untuk menyatakan standar perencanaan pemrograman yang baik harusmemiliki beberapa standar sebagai dasar dari evaluasi, seperti kemampuan memecahkan masalah dan pemrograman. Dari beberapa cara dalam mengatasi teknik pemecahan masalah standar, teknik topdown adalah metode pemecahan yang paling sering digunakan. Masalahmasalah yang kompleks akan dibagi menjadi beberapa tingkatan kelompok, yang menjadi bagian terkecil dari sub kelompok. Kemudian penyusunan langkahlangkah yang lengkap dan detail. Langkah-langkah rinci sering itu disebut algoritma.

\section{Hubungan Algoritma dan Pemrograman}

Algoritma dan bahasa pemrograman memiliki hubungan dengan suatu program. Dalam istilah pemrograman algoritma adalah sebagai nyawanya dan program adalah bahasanya sedangkan komputer adalah eksekutor. Apabila algoritma tersebut baik namun tidak memilih struktur data yang benar maka akan 
menghasilkan program yang tidak baik, begitu pula sebaliknya. Jika dikaitkan dengan program, gunakan Algoritma harus mematuhi aturan berikut:

1. Membuat atau menulis algoritma tidak bergantung pada bahasa. Ini berarti bahwa algoritme ditulis secara bebas dari bahasa pemrograman dan Komputer.

2. Notasi algoritma akan diterjemahkan ke bahasa pemrograman

3. Segala hal terkait bahasa pemrograman. Karena Output yang sama akan menghasilkan algoritma yang sama.

\section{Kesimpulan}

Kata algorism diambil dari nama seorang penulis terkenal dari bangsa Arab yakni Abu Ja'far Muhammad Ibnu Musa al-Khuwarizmi. Ia menciptakan sebuah buku yang diberi judul kitab aljabar wal-muqabala, dengan arti " Buku Pemugaran dan Pengurangan" ( The book of restoration and reduction)

Dapat disimpulkan definisi algoritma adalah ilmu yang membahas caracara penyelesaian sebuah persoalan dengan deretan langkah tertentu kemudian tersusun dengan sistematis dan memakai bahasa logis serta memiliki sebuah tujuan .

Asal dari kata pemrograman yaitu program yang artinya kumpulan instruksi yang dituliskan untuk melakukan suatu hal fungsi spesifik pada komputer, sedangkan pemrograman adalah segala sesuatu yang berkaitan dengan pembuatan program menggunakan komputer. Komputer memerlukan keberadaan program agar bisa menjalankan fungsinya sebagai komputer.

Algoritma dan bahasa pemrograman memiliki hubungan dengan suatu program. Apabila algoritmanya baik namun tidak memilih struktur data yang benar maka akan menghasilkan program yang tidak baik, begitu pula sebaliknya.

\section{DAFTAR PUSTAKA}

Ardyan, Stephanus, Mulyono dan Amin Suyitno. 2017. Implementasi Algoritma Dijkstra Dalam Pencarian Rute Terpendek Tempat Wisata di Kabupaten Gunungkidul Dengan Program Visual Basic. Jurnal Matematika FMIPA. Vo. 6, No. 2 .

Allen, A. d. (2020). Pengaruh Penerapan Algoritma Terhadap Pembelajaran Pemrograman Komputer. Jurnal Inovasi Pendidikan Matematika, Vol. 2. 
Bagus, Kadek dan Teristha Udayana. 2018. Penerapan Komponen dan Struktur Algoritma Pada Algoritma dan Pemrograman Dasar. Jurnal Bisnis dan Teknologi Politeknik. Vol. 5, No. 1.

Budiman, E. (2015). Belajar Dasar Algoritma dan Pemrograman. Samarinda: Pemula.

Dianta, I. A. (2019). Logika dan Algoritma Pemrograman. Semarang: Sekolah Tinggi Elektronika dan Komputer PAT Semarang. Hal: 1-13.

Indahyanti, Uce dan Yunianita Rahmawati. 2020. Algoritma Pemrograman Dalam Bahasa C++. Jawab Timur: UMSIDA Press.

Jati, S. B. (2015). Efektivitas Model Blended Learning Terhadap Motivasi dan Tingkat Pemahaman Mahasiswa Mata Kuliah Algoritma dan Pemrograman. Jurnal Pendidikan Vokasi, Vol. 5, Hal: 13.

Maulana, Gun Gun. 2017. Pembelajaran Dasar Algoritma dan Pemrograman Menggunakan El-Goritma Berbasi Web. Jurnal Teknik Mesin.Vol. 6, No. 2.

Mutia, F. (2021). Konsep Dasar Dalam Mempelajari Mata Kuliah Algoritma Pemrograman. Hal: 15 .

Retta, Allen Marga, Asnurul Isroqmi dan Tika Dwwi Nopriyanti. 2016. Pengaruh Penerapan Algoritma Terhadap Pembelajaran Pemrograman Komputer. Jurnal Inovasi Pendidikan Matematika. Vol. 02, No. 2, Hal: 126-135.

Samsudin, Indrawan dan Sri Mulyanti. 2020. Perancangan Sistem Informasi Pembelajaran Algoritma dan Pemrograman Berbasis Web Pada Program Studi Teknik Informatika STMIK ERESHA. Jurnal Informatika. Vol. 5, No.

4, Hal: 521-528

Yahfizham, Kasmana Rukun, Krismadinata, Ganefri, Sukardi dan Wizwardi Jalinus. 2018. Pembelajaran Pada Mata Kuliah Elektronika Daya: Suatu Kajian Literatur. Jurnal Pendidikan Teknologi dan Kejuruan. Vol. 15, No. 2, Hal: 157 . 
Artikel-05-Tsania_Khairani_0305201018.pdf

ORIGINALITY REPORT

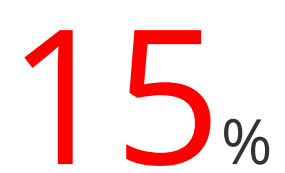

SIMILARITY INDEX

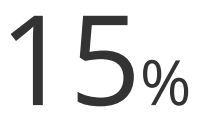

INTERNET SOURCES
$3 \%$

PUBLICATIONS
$6 \%$

STUDENT PAPERS

PRIMARY SOURCES

1 dantiaisyah09.wordpress.com Internet Source

2 www.nesabamedia.com Internet Source

3 vaskoedo.wordpress.com

4 es.scribd.com

5 docplayer.info Internet Source

6 nyohongo.wordpress.com Internet Source

7 rjsanwar45.blogspot.com 
Nofiyanto Nofiyanto, Hamzah Hamzah,

Herison Surbakti. "SHORT MESSAGE

ENCRYPTION APPLICATION DEVELOPMENT

USING VIGENERE ALGORITHM UTILIZING

EULER'S NUMBER ON ANDROID

SMARTPHONE", Respati, 2017

Publication

11 dyastyas11.blogspot.com

Internet Source

12 Submitted to STT PLN

Student Paper

13 core.ac.uk

Internet Source

14 blogaraya.blogspot.com

Internet Source

15 herusulistiono.gitbook.io

16 muhammaderyramdan.blogspot.com

17 yyulianti8.blogspot.com

Internet Source

18 jurnal.univpgri-palembang.ac.id 


\section{0 adychastanyo.blogspot.com}

